\title{
Integration of A Solid Oxide Fuel Cell into A 10 MW Gas Turbine Power Plant
}

\author{
Denver F. Cheddie \\ Center for Energy Studies, Point Lisas Campus, University of Trinidad and Tobago, Esperanza Road, \\ Brechin Castle, Couva, Trinidad and Tobago; E-Mail: denver.cheddie@utt.edu.tt; \\ Tel.: +1-868-343-5014; Fax: +1-868-636-3339
}

Received: 4 February 2010 / Accepted: 9 March 2010 / Published: 14 April 2010

\begin{abstract}
Power generation using gas turbine power plants operating on the Brayton cycle suffers from low efficiencies. In this work, a solid oxide fuel cell (SOFC) is proposed for integration into a $10 \mathrm{MW}$ gas turbine power plant, operating at $30 \%$ efficiency. The SOFC system utilizes four heat exchangers for heat recovery from both the turbine outlet and the fuel cell outlet to ensure a sufficiently high SOFC temperature. The power output of the hybrid plant is $37 \mathrm{MW}$ at $66.2 \%$ efficiency. A thermo-economic model predicts a payback period of less than four years, based on future projected SOFC cost estimates.
\end{abstract}

Keywords: thermo-economic model; solid oxide fuel cell; gas turbine; hybrid power plant

\section{Introduction}

Fuel cells are electrochemical devices that convert the chemical energy in a fuel into electricity without direct combustion. As a result, they avoid many of the limitations of combustion engines, providing more energetically and exergetically efficient fuel to power conversion. Solid oxide fuel cells (SOFC) are best suited for stationary power generation (centralized and distributed). They operate at temperatures between $600-1100{ }^{\circ} \mathrm{C}$ and have been tested at operating pressures up to 15 atm [1]. Because of their high temperature and pressure exhaust, SOFCs are considered ideal for integration in hybrid power generating systems, where their outlet gas streams are expanded in a gas turbine (GT) to produce additional power.

SOFC hybrid power systems have received considerable interest in the literature over the past 5-10 years. Zhang et al. [2] gave a comprehensive list of strategies for integrating SOFCs with other power generating components. These schemes can be categorized as direct thermal coupling, 
indirect thermal coupling and fuel coupling. Direct thermal coupling involves two or more power systems (e.g., SOFC and GT) sharing the same working fluid. In indirect thermal coupling, different working fluids are kept separate; only heat is transferred between the two power systems via heat exchangers. SOFC-GT systems are best suited for direct thermal coupling because they both work with the same working fluid in the same temperature and pressure range. Coupling a SOFC with a steam turbine (ST) on the other hand, best works indirectly with exhaust heat from the SOFC being used to evaporate steam. Fuel coupling schemes involve the configuring of the integration system to include hydrogen production or fuel reforming.

Many of the SOFC-GT schemes presented in the literature involve direct thermal coupling. There are only a few prototype hybrid power plants in existence [3-5], primarily because of the prohibitive cost of SOFC technology, so researchers resort to mathematical modeling to predict the performance of hybrid power plants. Typical thermodynamic models are based on mass and energy balances across various components, normally treated as zero dimensional. Equations for each component based on the first and second laws of thermodynamics are used to develop a system of equations which can be solved to determine the state properties at each point in the hybrid power cycle.

Massardo and Lubelli [6] developed a thermodynamic model for a multi-MW demonstration plant based on an internally reforming SOFC and gas turbine cycles. Chan et al. [7] added an exergy analysis to a SOFC model, a concept which was later incorporated into hybrid plant models [8-14]. Akkaya et al. [14] introduced an exergetic performance coefficient to quantify the second law thermodynamic performance of the hybrid plant, and allowed for easy identification of the chief sources of exergy destruction in the plant. Burbank et al. [15] considered a pressurized SOFC-GT engine which entailed a variable geometry nozzle turbine to directly influence the airflow as well as an auxiliary combustor to control the temperature of turbomachinery. They found that this plant could operate over a 5:1 turndown ratio. Song et al. [12] and Calise et al. [16] modeled part load operating conditions of hybrid plants. Both found that the best control strategy for part load operation was simultaneously varying the air and fuel flow rates while maintaining a constant air/fuel ratio. This was necessary to keep the SOFC and GT operating as close to their design temperatures at all times. Calise et al. [16] found that using this strategy the efficiency dropped from $64.5 \%$ at full load to $45 \%$ at $34 \%$ load. Franzoni et al. [17] modeled a plant which considered carbon dioxide separation. It was found that condensing the exhaust steam enabled the separation of the $\mathrm{CO}_{2}$ in the outlet, however decreased system efficiency from 61.7 to $58.9 \%$.

Various researchers added economic assessments to their thermodynamic analyses. Palazzi et al. [18] discussed thermo-economic optimization techniques using pinch based methods. Arsalis [19] performed a detailed thermo-economic assessment of a 1.5-10 MWe hybrid system. They found that for small SOFCs cost minimization is the critical optimization goal, while for large SOFCs efficiency maximization is the key optimization goal. Santin et al. [20] considered the use of liquid fuels (methanol and kerosene) instead of methane/natural gas primarily because of their ease of transport. For a $500 \mathrm{~kW}$ plant, they found that the use of methanol instead of methane reduced the plant efficiency by up to $7 \%$, however reduced the payback period on the investment by 0.5 years. This was because of the lower capital cost associated with handling methanol. 
The goal of thermo-economic analyses is to maximum system efficiencies, minimize irreversibilities or maximize the cost benefit. Various optimization techniques have been presented in the literature. Single-level modeling aims to optimize the entire system as a whole [21], while multi-level modeling seeks to simultaneously optimize multiple subsystems [22,23]. Calise et al. [21] argue that single level optimization produces similar results to multi-level efforts with less difficulty.

Although most of the literature thus far has been devoted to steady state analysis, dynamic modeling has also been attempted. Zhang et al. [24] modeled the dynamic performance of the SOFC on the basis of exponential decay and exponential associate functions. Kandepu et al. [25] developed a dynamic model based on lumped capacitance modeling and mass and energy conservation. However, most dynamic models focus on the SOFC rather than the entire power plant.

A wide scale of operation has been considered ranging from $\mathrm{kW}$ to MW. Most existing SOFC-GT hybrid plants are in the $\mathrm{kW}$ range [3-5], however larger plants have been modeled in the literature. Chan et al. [22] considered a 1.3 MW plant, which consisted of a SOFC stack with 40,000 tubular cells. Arsalis [21] considered SOFC stacks up to 8.5 MW for a SOFC-GT-ST hybrid system. Their SOFC stack was modeled up to $1100{ }^{\circ} \mathrm{C}$ and 10 bar. They propose a system of this magnitude to provide distributed power for 2000 households. Their thermo-economic analysis showed that using a larger size SOFC results in better thermodynamic performance, but add significantly to the system costs since the SOFC cost dominates the capital cost in new hybrid systems. They also discussed the inherent difficulty in selecting a gas turbine for small scale operation since their efficiencies decrease as the system scales down. One of the advantages of large scale operation is that, in theory, SOFC technology can easily be scaled up by adding more stacks. However, there are practical issues that must be considered, such as localized hotspots and unbalanced loading on each stack. Singhal and Kendall [26] and Larminie and Dicks [27] expect that practical SOFC systems will be scaled up from $100 \mathrm{~kW}$ to $10 \mathrm{MW}$ prior to commercialization of the technology [21].

Most modeling efforts have focused on small scale applications ( $<1 \mathrm{MW})$. Typically, a specific SOFC stack is used, and a micro-turbine is selected to best match the SOFC stack for optimal hybrid performance. In the present work, the objective is not to design new micro power plants, but to use SOFC technology to optimally retrofit existing power plants. Large scale gas turbines already exist in these plants, and the objective is to select an optimally sized SOFC stack that best matches the existing system. For a large plant, all that is needed is a larger number of SOFC sub-stacks. As a case study, a $10 \mathrm{MW}$ gas turbine power generation unit is considered, which entails a compression ratio of 10 and a turbine inlet temperature of $1400 \mathrm{~K}$. A thermo-economic model is developed for this system to optimally size the SOFC stack to obtain the most cost effective performance of the system.

\section{Model Development}

\subsection{Schematic}

The existing power plant (hereafter referred to as the standard plant) is based on the standard Brayton cycle using natural gas to provide heat input. In this paper, natural gas is considered to be mostly methane with other components providing negligible contribution. It utilizes a compression ratio of 10 , followed by combustion of natural gas (methane) to provide sufficient heat to achieve a 
turbine inlet temperature of $1400 \mathrm{~K}$. The products of combustion are then expanded in the turbine back down to atmospheric pressure. Methane is consumed at a rate of $40.0 \mathrm{~kg} / \mathrm{min}$ in the combustion processes. The isentropic efficiencies $(82.3 \%$ and $86.0 \%$ for the compressor and turbine, respectively) and combustion efficiency $(98.9 \%)$ are calculated from experimental data. At the time the measurements were taken, the plant was operating at full load, producing $10.6 \mathrm{MW}$ of net power at a thermal efficiency of $30.0 \%$. The second law thermodynamic efficiency is $13.7 \%$. The energy and exergy breakdown for this standard plant are shown in Table 1. Typically, in power plants operating under the standard Brayton cycle with heat input coming from combustion of carbon based fuels, the first and second law thermodynamic performances are poor.

Table 1. Exergy breakdown of the standard $10 \mathrm{MW}$ plant.

\begin{tabular}{lccc}
\hline Process & Heat Input (MW) & Power Output (MW) & Irreversibility (MW) \\
\hline Compression & & -12.1 & 1.1 \\
Combustion & 33.5 & & 11.4 \\
Expansion & & 22.1 & 1.3 \\
\hline TOTAL & 33.5 & 10.0 & 13.8 \\
$1^{\text {st }}$ Law Efficiency & $30.0 \%$ & $2^{\text {nd }}$ Law Efficiency & $13.7 \%$ \\
\hline
\end{tabular}

Figure 1 shows the proposed hybrid configuration that is aimed at improving the thermodynamic and economic performance of the power plant. In this configuration, the goal is to replace the combustion engine with the more efficient SOFC technology. The fuel cell considered is the Westinghouse tubular SOFC technology. However, since the fuel cell does not operate at $100 \%$ fuel utilization, an afterburner is still needed to combust excess fuel prior to expansion in the gas turbine. Note that the existing combustion device can be used as the afterburner. This afterburning process also serves to increase the turbine inlet temperature to $1400 \mathrm{~K}$ to achieve maximum power output from the turbine while adhering to material thermal constraints. Unlike a combustion engine, the SOFC is very sensitive to its temperature of operation. So in the hybrid power plant, it is essential to preheat the inlet gas streams prior to entry into the fuel cell. This is accomplished via heat recovery using the turbine exhaust. There are various possible heat exchanger configurations, but in this work, separate heat exchangers are used to preheat the incoming air, fuel and to evaporate water for reformation. The exhaust from the gas turbine is used as the hot fluid in the heat exchangers. Also, heat exchangers are also located within the fuel cell unit, whereby the outlet gases from the SOFC are used to preheat the inlet gases in order to elevate the SOFC operating temperature.

\subsection{Assumptions}

The schematic shown in Figure 1 applies for full load operating point conditions. There are numerous contingencies that are deliberately not shown to avoid complicating the figure. For example, typically a stream from the air compressor is bled to the turbine inlet stream as a control mechanism to prevent the turbine inlet temperature from exceeding $1400 \mathrm{~K}$. However, at the designed operating conditions, this flow will be zero. This ideal design condition is represented in Figure 1. These contingencies are understood, but not shown. Since this work is not interested in the design of control 
mechanisms, this aspect of the plant design is not of relevance here. Steady state full load conditions are studied in this paper. Future works will focus on part load and time dependent performance.

Figure 1. Schematic of the proposed hybrid power plant.

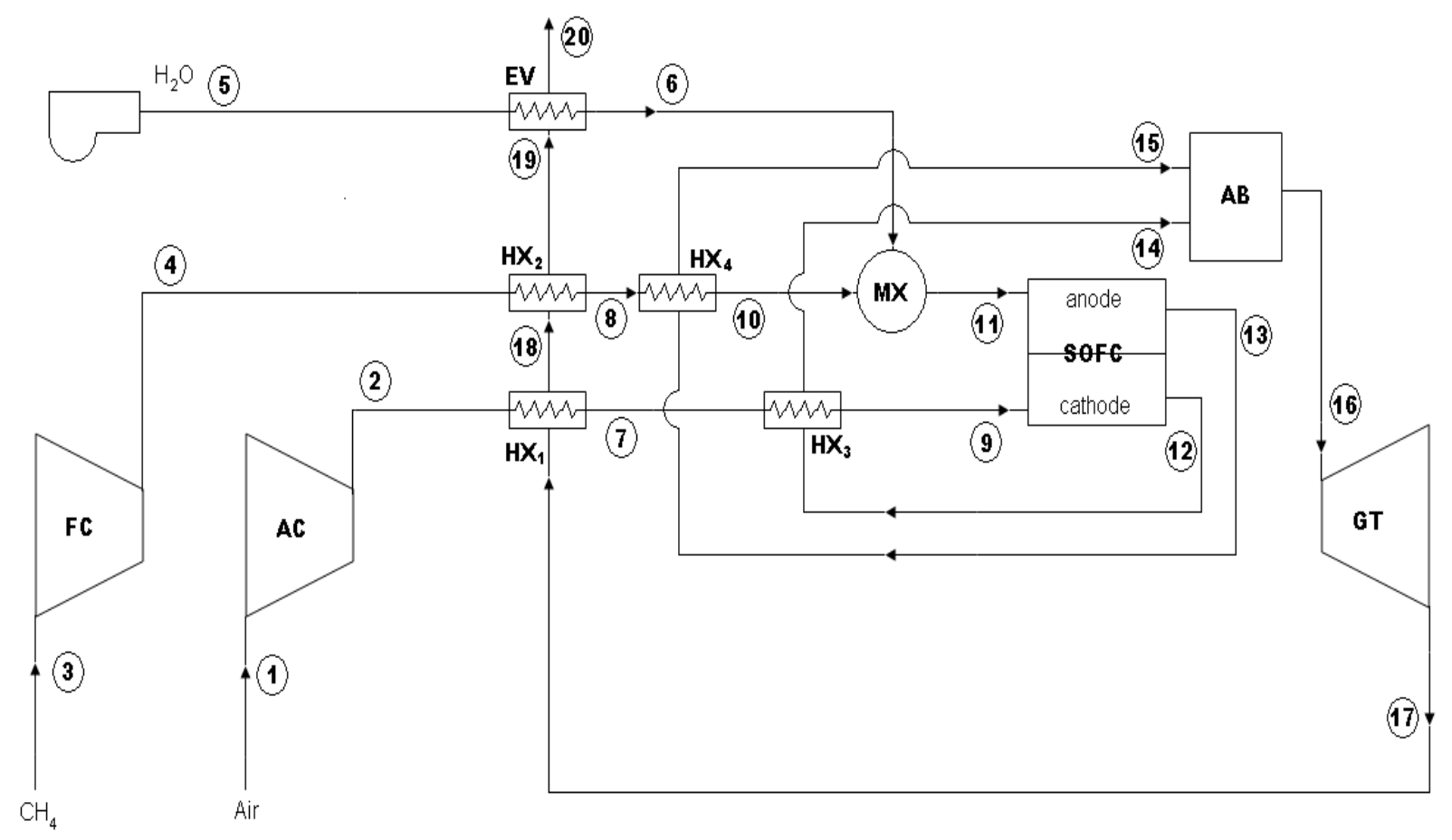

Full combustion is also assumed. Combustion efficiency is taken to mean that $100 \%$ oxidation of the fuel occurs, however some of the heat of combustion is "lost" to the environment. It is also assumed for convenience that all the heat losses to the environment take place at the combustion device. All other components are considered to be insulated from the environment. Direct internal reforming SOFCs are considered in this paper, however the thermodynamic analysis would still apply if an external reformer were used since the thermodynamic analysis of the fuel cell presented in this paper applies to the entire fuel cell system. The only factor that would be affected is the additional capital cost. It is also assumed that complete reformation of methane takes place in the reforming section of the SOFC, and that only hydrogen, carbon dioxide and water vapor exist in the anode section of the SOFC. Future works will consider the effects of incomplete reformation and the presence of carbon monoxide as a fuel in the anode.

\subsection{Equations}

In this work, a lumped approach is used to analyze each component of the plant. Mass and energy balances are considered across each component, the first and second laws of thermodynamics are applied to determine outlet states and exergy destruction.

$$
Q-W=\Delta H
$$


For all processes, the irreversibility or exergy destruction,

$$
I=T_{0}\left(\Delta S-\sum_{i} \frac{Q_{i}}{T_{i}}\right)
$$

In this paper the first law thermodynamic efficiency is defined as the ratio of net electrical power output to total heat input. The second law thermodynamic efficiency is defined as the ratio of net power output to the total exergy input.

$$
\begin{gathered}
\eta_{I}=\frac{W_{n e t}}{Q_{i n}} \\
\eta_{I I}=\frac{W_{n e t}}{E x_{i n}}
\end{gathered}
$$

The enthalpy and entropy values of each gas species are determined from coefficients used in Reference [28]. The enthalpy values already account for the heat of formation at $298 \mathrm{~K}$. The entropy calculations include physical and chemical exergies. For a gas mixture at temperature $\mathrm{T}$ and pressure $\mathrm{P}$, the enthalpy and entropy are determined from Equations 5 and 6.

$$
\begin{gathered}
H=\sum\left(n_{i} h_{i}^{T}\right) \\
S=\sum\left[n_{i}\left\{s_{i}^{T, p_{0}}-R \log \left(\frac{p_{i}}{p_{0}}\right)\right\}\right]
\end{gathered}
$$

Combustor, Mixer and Heat Exchangers

In the combustion chamber, no work is done; therefore the first law applies, where only the heat losses to the environment need to be considered. The heat of reaction is already incorporated in the outlet enthalpy values. The outlet composition is determined from a molar balance assuming complete combustion of methane and hydrogen. Excess air is assumed to ensure complete combustion.

$$
\begin{gathered}
\mathrm{CH}_{4}+2 \mathrm{O}_{2} \rightarrow \mathrm{CO}_{2}+2 \mathrm{H}_{2} \mathrm{O} \\
2 \mathrm{H}_{2}+\mathrm{O}_{2} \rightarrow 2 \mathrm{H}_{2} \mathrm{O}
\end{gathered}
$$

For known inlet conditions, the combustion outlet temperature is determined so as to ensure Equation 1 is satisfied. An iterative approach based on the Newton-Raphson method, is used in this work to accomplish this goal.

$$
\sum\left(n_{i} h_{i}^{T}\right)_{\text {out }}=-Q_{\text {loss }}+\sum\left(n_{i} h_{i}^{T}\right)_{\text {in }}
$$

Mixing processes are treated in an identical manner, except that the outlet composition is merely the algebraic sum of all inlet compositions. The outlet temperature of mixing devices is determined in the same manner as the combustion devices.

The heat exchangers also employ energy conservation since it is assumed that no heat is lost to the environment. The difference is that the hot and cold streams are not mixed, hence they maintain a given composition. There are two outlet streams, hence two outlet temperatures need to be determined. The effectiveness-NTU [29] method is used to determine the actual temperature changes to both the 
cold and hot fluid, based on the heat exchanger type, effective heat transfer coefficient and surface area.

$$
\Delta H_{\text {cold }}+\Delta H_{\text {hot }}=0
$$

For a counter flow type heat exchanger,

$$
\begin{gathered}
\varepsilon=\frac{1-\exp \left[-N T U\left(1+C_{r}\right)\right]}{1+C_{r}} \\
C_{r}=\frac{C_{\min }}{C_{\text {max }}} \\
N T U=\frac{U A}{C_{\text {min }}} \\
Q_{\text {max }}=C_{\text {min }}\left(T_{\text {in }}^{\text {hot }}-T_{\text {in }}^{\text {cold }}\right) \\
Q=\Delta H_{\text {cold }}=-\Delta H_{\text {hot }}=\varepsilon Q_{\text {max }}
\end{gathered}
$$

Compressors and Turbine

Practically, compressor and turbine maps are used to determine the operating isentropic efficiencies given the temperature, pressure and flow rates. However in this particular work, determining the operating conditions of the compressor and turbine are not of interest, since it does not entail the design and selection of appropriate compressors and turbines. In the present power plant, the compressors and turbine already exist. The present work is only interested in retrofitting the existing plant to replace as much combustion with fuel cell processes, so it is desired to maintain "normal" operation of the compressor and turbine. As a result, the inlet conditions to the turbine and compressor, as well as their respective isentropic efficiencies are already known. The only minor difference is that a different amount of fuel will be handled in the hybrid plant than in the standard plant, making the flow rate handled by the turbine greater than before. However, it is assumed that this slight change in flow rate will not significantly affect the isentropic efficiency of the turbine. So in this work, there is no need to determine the isentropic efficiencies since they are already known from analysis of the existing power plant.

$$
\begin{gathered}
W=-\Delta H \\
\eta_{s}=\left\{\begin{array}{l}
\frac{W}{W_{s}} \text { for turbine } \\
\frac{W_{s}}{W} \text { for compressor }
\end{array}\right.
\end{gathered}
$$

Solid Oxide Fuel Cell

The SOFC produces DC power via electrochemical processes. The methane is reformed inside the anode compartment, producing hydrogen which is electrolyzed in the SOFC. The SOFC in question 
has a $75 \%$ fuel utilization factor, such that the following reformation, shift and half cell reactions take place at the respective electrodes.

$$
\begin{gathered}
\mathrm{CH}_{4}+\mathrm{H}_{2} \mathrm{O} \rightarrow \mathrm{CO}+3 \mathrm{H}_{2} \\
\mathrm{CO}+\mathrm{H}_{2} \mathrm{O} \rightarrow \mathrm{CO}_{2}+\mathrm{H}_{2} \\
\mathrm{H}_{2}+\mathrm{O}^{2-} \rightarrow \mathrm{H}_{2} \mathrm{O}+2 e^{-} \\
\frac{1}{2} \mathrm{O}_{2}+2 e^{-} \rightarrow \mathrm{O}^{2-}
\end{gathered}
$$

In this paper, $x$ is taken as the molar ratio of methane to oxygen entering the plant. Thus all the calculations are performed on a per molar oxygen basis. For a given fuel utilization factor, $x$ is directly proportional to the current density produced by the SOFC.

$$
i=\frac{U_{f} \cdot 8 x \cdot F \cdot N_{O_{2}}}{A_{S O F C}}
$$

The operating cell voltage is determined from subtracting all overpotentials (activation, ohmic and concentration) from the standard Nernst potential at the given temperature and pressure.

$$
\begin{gathered}
E=-\frac{G_{0}}{2 F}+\frac{R T}{2 F} \log \left(\frac{p_{\mathrm{H}_{2}}}{p_{\mathrm{H}_{2} \mathrm{O}}} \sqrt{\frac{p_{\mathrm{O}_{2}}}{p_{\text {atm }}}}\right) \\
V_{\text {cell }}=E-\left(\eta_{\text {activation }}+\eta_{\text {ohmic }}+\eta_{\text {concentrabn }}\right) \\
i=i_{0}\left[\exp \left(\alpha \frac{n F}{R T} \eta_{\text {act }}\right)-\exp \left(-(1-\alpha) \frac{n F}{R T} \eta_{\text {act }}\right)\right] \\
i_{0, \text { anode }}=\gamma_{\text {anode }} \frac{p_{\mathrm{H}_{2}}}{p_{\text {ref }}} \frac{p_{\mathrm{H}_{2} \mathrm{O}}}{p_{\text {ref }}} \exp \left(-\frac{E_{\text {act,an }}}{R T}\right) \\
i_{0, \text { cathode }}=\gamma_{\text {cathode }}\left(\frac{p_{\mathrm{O}_{2}}}{p_{\text {ref }}}\right)^{1 / 4} \exp \left(-\frac{E_{\text {act,ca }}}{R T}\right) \\
\eta_{\text {conc }}=\frac{R T}{2 F} \log \left(1-\frac{i}{i_{\text {lim }}}\right)
\end{gathered}
$$

Constants for the ohmic and activation parameters are given elsewhere [30]. The work or power output from the SOFC is the product of total current and cell voltage. The SOFC produces DC power which must be inverted to an AC output. An inverter efficiency of $98 \%$ is assumed in this work.

The heat of reaction can be determined from an equation typically used in the literature.

$$
Q_{S O F C}=i\left(\eta_{\text {total }}-\frac{T \Delta S}{n F}\right) A_{S O F C}
$$

However, this heat generation, Equation 29, was derived assuming isothermal operation of the fuel cell. In reality, there is a temperature increase from inlet to outlet of the SOFC. So the entropy change given in that equation is not the actual entropy change across the fuel cell. Figure 2 illustrates this point. To use Equation 29, the fuel cell must be considered isothermal, with the computed heat generation 
based on the isothermal operating temperature. This generated heat then serves to enable the reformation reactions and post heat the products of the fuel cell reaction. However if we consider the fuel cell system shown in Figure 2, it is evident that the fuel cell outlet temperature can be determined without a direct computation of the heat generation. Applying the first law of thermodynamics to the entire fuel cell system, the following equation applies.

$$
W_{\text {SOFC }}=i V_{\text {cell }} A_{\text {SOFC }}=-\Delta H_{\text {SOFC }}
$$

The fuel cell operating temperature in a lumped parameter model is typically taken as the outlet temperature [7] since the inlet gas streams are preheated inside the fuel. This is especially the case in injection tube SOFCs. The SOFC stack is typically designed in such a way as to minimize temperature gradients and hence thermal shock. Thus a fairly uniform spatial temperature distribution is actually achieved in SOFC design. As a result, the outlet temperature (assumed common for both anode and cathode) can be taken as the operating cell temperature. This value is determined using Equation 30 and an iterative approach.

Figure 2. Fuel cell thermodynamic processes.

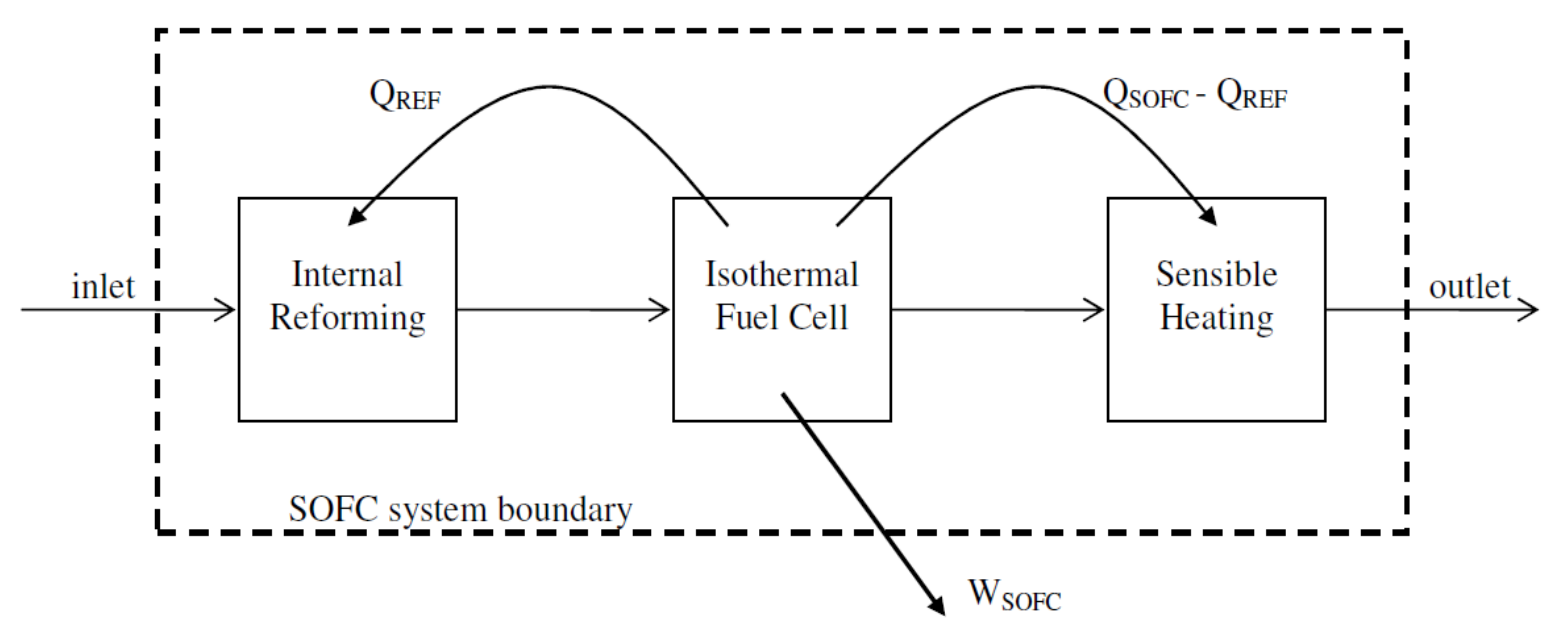

\section{Cost Functions}

The economic analysis of the plant entails the capital costs associated with the SOFC and other related equipment, e.g., heat exchangers, reformers, afterburners, inverters, etc. Presently the cost of SOFC technology is prohibitive, however the cost analysis in this work is based on projected mass production costs when the technology matures [19]. These projected capital costs are shown below respectively for the SOFC, inverter, pre-reformer, and counter flow heat exchanger. Capital costs for other auxiliary equipment such as tubing, mixers, valves are taken as $10 \%$ of the capital cost of the SOFC.

$$
\begin{gathered}
C_{S O F C}=A_{S O F C}\left(2.96 T_{S O F C}-1907\right) \\
C_{\text {inverter }}=10^{5}\left(\frac{W_{\text {SOFC }}}{500}\right)^{0.7}
\end{gathered}
$$




$$
\begin{gathered}
C_{\text {pre-reformer }}=130\left(\frac{A_{P R}}{0.093}\right)^{0.78}+3240\left(V_{P R}\right)^{0.4}+21280.5\left(V_{P R}\right) \\
C_{H X}=130\left(\frac{A_{H X}}{0.093}\right)^{0.78} \\
C_{S O F C, \text { aux }}=0.1\left(C_{\text {SOFC }}\right)
\end{gathered}
$$

The hybrid power plant produces extra power (greater than the standard plant due to the introduction of the SOFC), but at a higher rate of fuel consumption. Associated with the additional power generation is an annual economic benefit, evaluated at an electricity cost of USD $\$ 0.05 / \mathrm{kWh}$. The additional fuel cost is evaluated at USD \$3.50 /MBTU of methane (natural gas). All costs are converted to net present value (NPV) using a $9 \%$ interest rate over a 10 year life cycle.

The enthalpy and entropy equations for each species are programmed as user defined functions into MATLAB. Sub-routines for each component as well as cost functions are then written in MATLAB's programming language. These sub-routines iteratively determine the outlet conditions (temperature and composition) of each component given the inlet conditions. When inlet conditions are unknown, they are initially guessed and iteratively determined. All sub-routines are combined into one plant algorithm which is used to determine all state properties, and hence optimize the hybrid power plant.

\section{Results and Discussion}

\subsection{Model Validation}

The SOFC model is validated using experimental data published in References [21,30,31] (Figure 3). Experimental data are based on $89 \% \mathrm{H}_{2}$ and $11 \% \mathrm{H}_{2} \mathrm{O}$ at the anode fuel, and operation at $1000{ }^{\circ} \mathrm{C}$ and 1 atm. Unfortunately, data is not readily available for SOFC performance using methane or natural gas, thus the internal reformation aspect of the SOFC cannot be validated at this time. The model predictions for a hydrogen cell are within $\pm 2.3 \%$ of the experimental data.

Figure 3. SOFC polarization curve (hydrogen, $1273 \mathrm{~K}, 1 \mathrm{~atm}$ ).

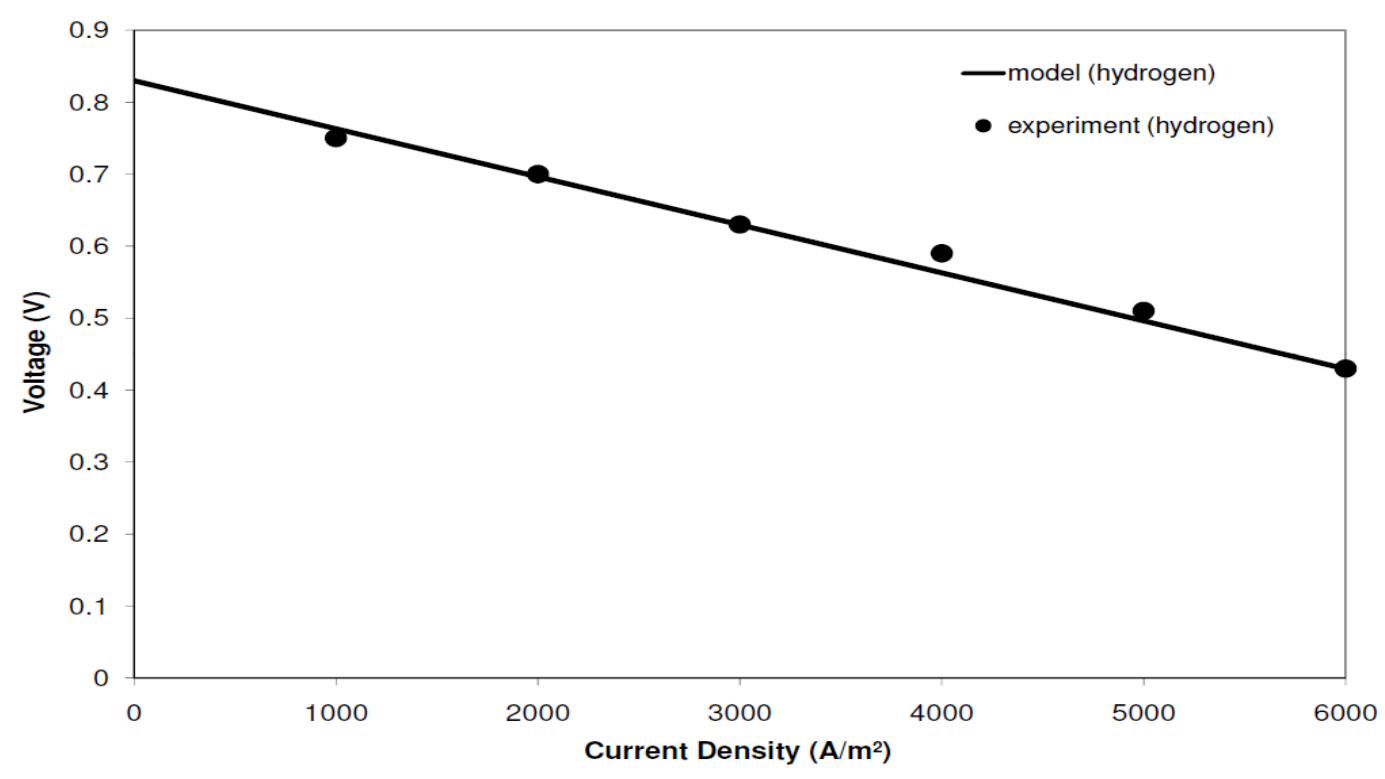


The model is then used to predict the SOFC performance for the internally reforming SOFC using methane. Figures 4 and 5 show the polarization curves as a function of pressure and temperature, respectively. As expected, increasing the pressure results in lower overpotentials because of the higher partial pressures of hydrogen and oxygen at the triple phase boundaries. However, the polarization curves are much more sensitive to temperature. Activation parameters and ohmic resistances are both strongly dependent on temperature. As a result, the performance of the SOFC drastically improves with temperature. Thus it is critical to maintain a sufficiently high operating temperature for the SOFC in order to ensure efficient performance.

Figure 4. SOFC polarization curve as a function of pressure (methane, $1273 \mathrm{~K}$ ).

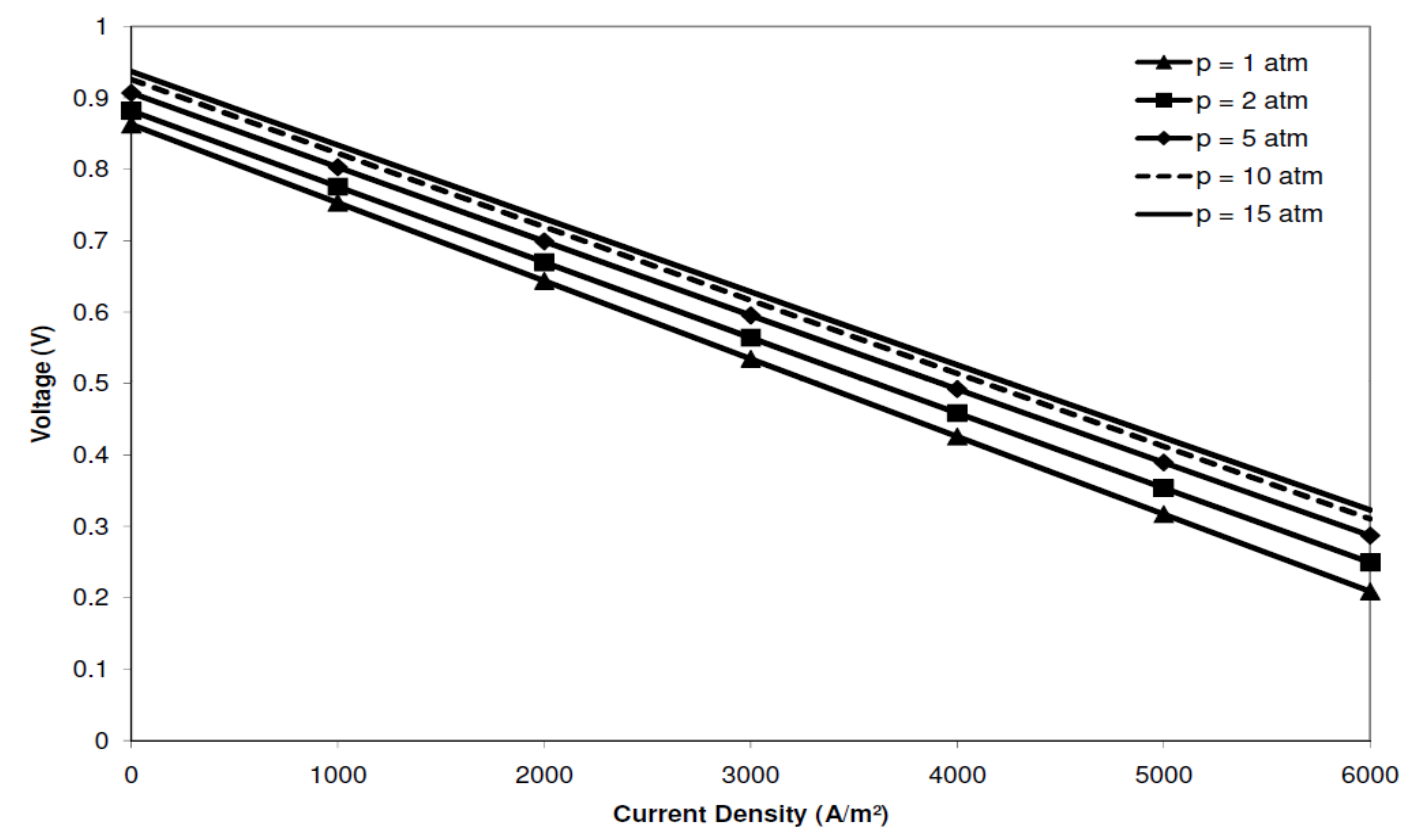

Figure 5. SOFC polarization curve as a function of temperature (methane, $10 \mathrm{~atm}$ ).

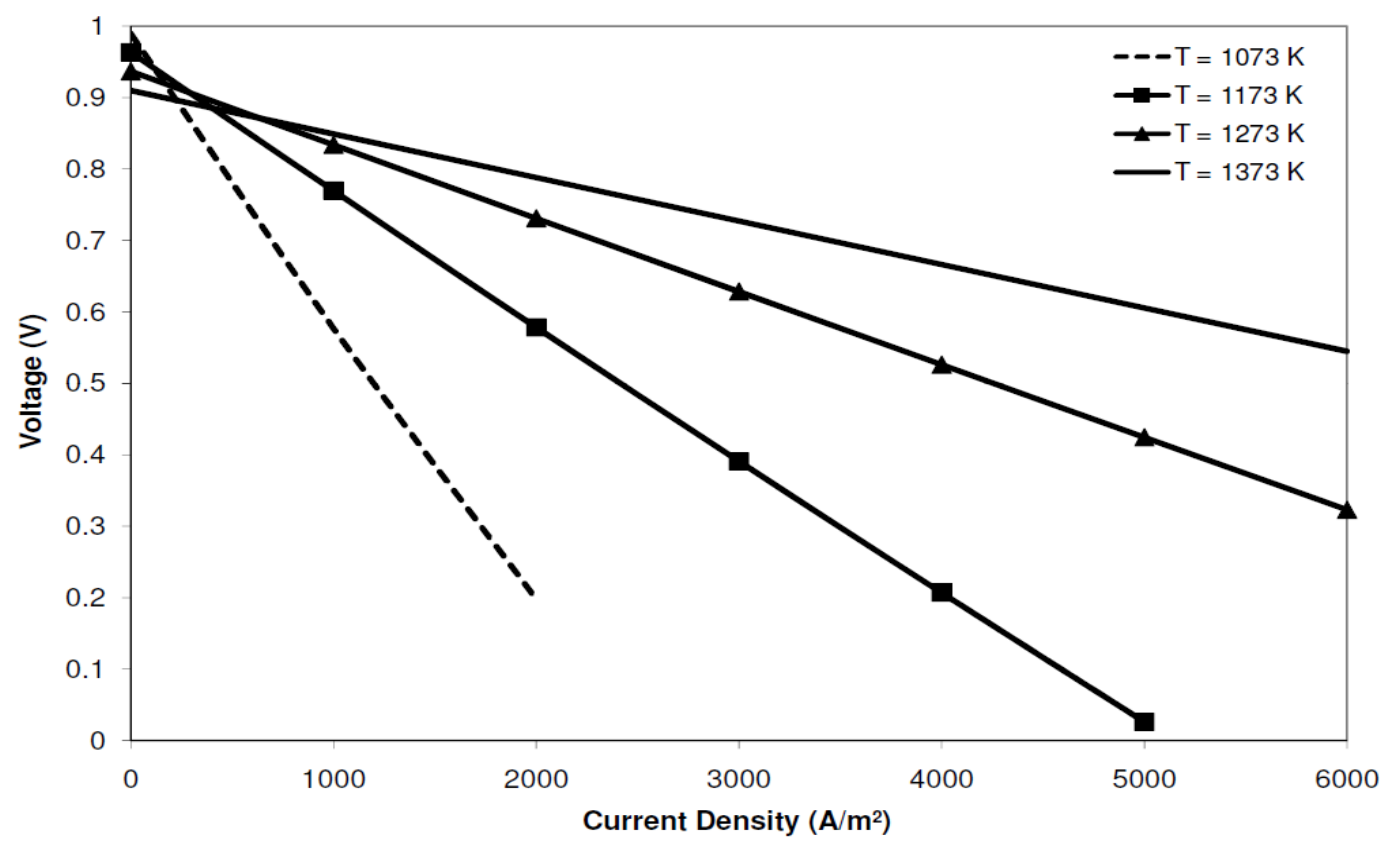




\subsection{Power Plant Optimization}

Table 1 shows the energy and exergy breakdown of the existing power plant (Brayton cycle). It shows a first law efficiency of $30.0 \%$ and irreversibilities amounting to $13.8 \mathrm{MW}$ (exceeding the power output of the plant). Most of these irreversibilies are due to the combustion processes, as expected. The second law efficiency is $13.7 \%$. The hybrid plant seeks to replace most of the combustion processes with the more efficient fuel cell. The optimization objective is to find the size of the SOFC (measured by its effective surface area) that maximizes the NPV, while supplying sufficient fuel to maintain a turbine inlet temperature of $1400 \mathrm{~K}$. The efficiencies, total power output and NPV are plotted against the SOFC surface area, and the results are presented in Figure 6 and 7. Both the power and efficiencies increase with SOFC area. This is because as the SOFC area increases, the contribution of the total power by the more efficient SOFC increases. However, the NPV reaches a peak of $\$ 34.9 \mathrm{M}$ when a $7000 \mathrm{~m}^{2}$ cell is used. The reason the NPV curve reaches a peak is because as the SOFC size increases, the plant efficiency tends to that of a stand-alone SOFC, i.e., it increases asymptotically. The capital cost, on the other hand, increases almost linearly with SOFC size. The NPV curve displays a large plateau, which means that from 7000 to $10,000 \mathrm{~m}^{2}$, there is little difference in the NPV. However according to Figure 7, from 7000 to $8000 \mathrm{~m}^{2}$, there is a sharp increase in the cell voltage of the SOFC. There is also a notable drop in SOFC temperature. At $7000 \mathrm{~m}^{2}$ the SOFC temperature is too high, thus using the larger size SOFC will serve to decrease the SOFC temperature while increasing the cell voltage. Thus $8000 \mathrm{~m}^{2}$ is considered to be the optimal size of the SOFC unit required to best match the gas turbine. The first and second law efficiencies for the $8000 \mathrm{~m}^{2}$ cell are $66.2 \%$ and $47.0 \%$ respectively. The SOFC contributes $23.4 \mathrm{MW}$ of the total $37.0 \mathrm{MW}$ produced by the plant. Also the SOFC operates at $1410 \mathrm{~K}$ and a cell voltage of $0.58 \mathrm{~V}$. It should be noted that Figure 7 shows the theoretical performance predicted by the model, and that the model does not know of the SOFC material thermal constraints. The region of Figure 7 where the SOFC temperature greatly exceeds $1400 \mathrm{~K}$ is simply viewed as the un-usable portion of the graph.

Figure 6. Optimization of the hybrid power plant.

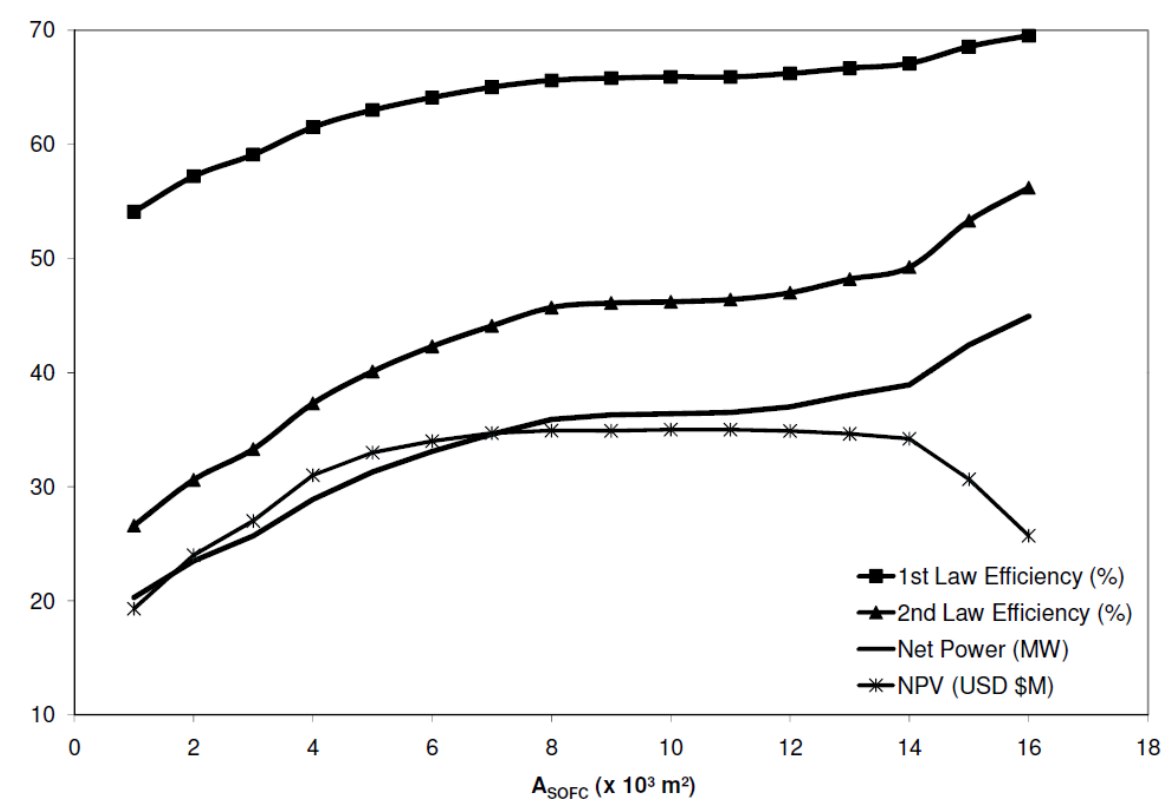


Figure 7. SOFC temperature and voltage versus SOFC area.

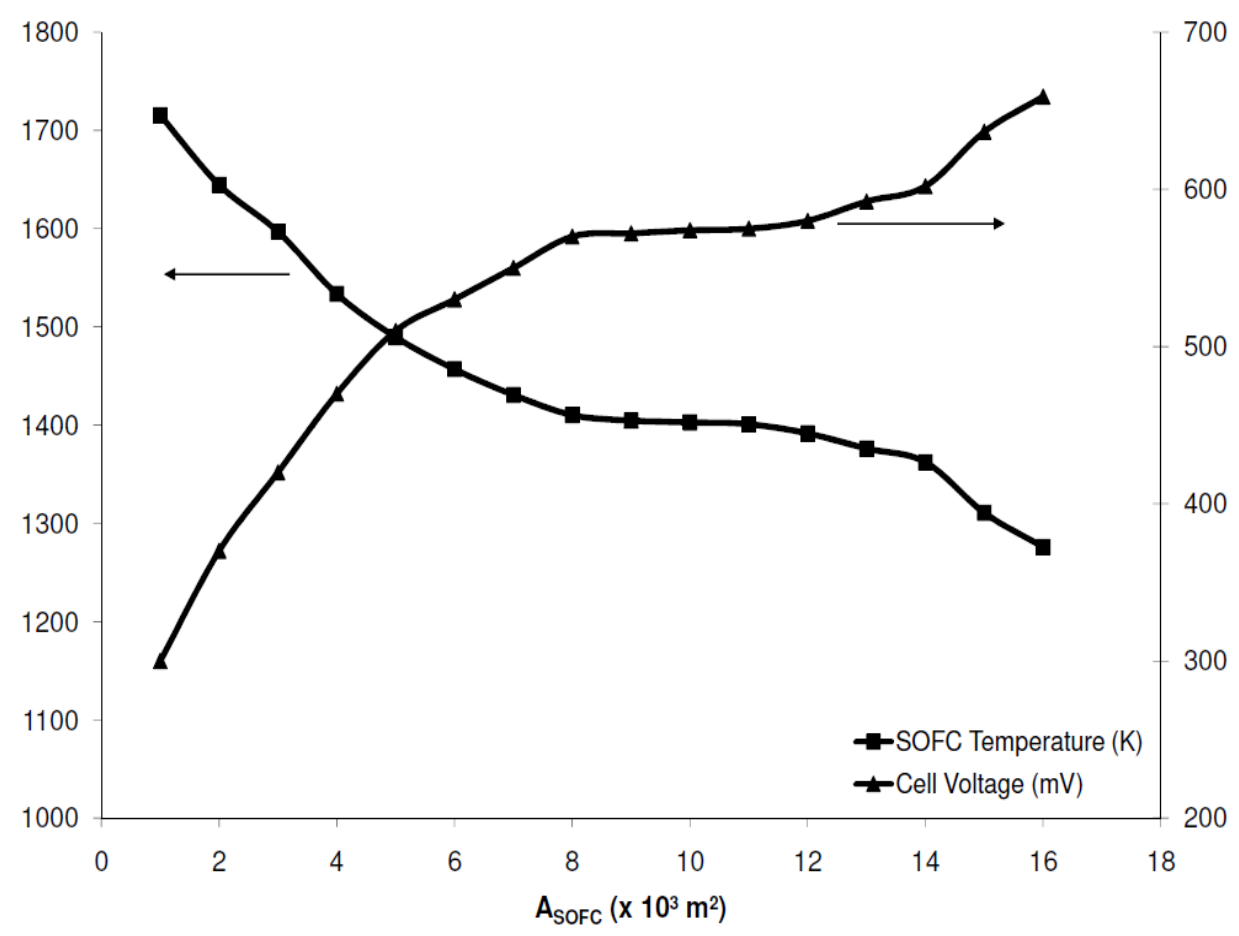

The energy and exergy breakdown for this optimized hybrid plant is shown in Table 2. It is noteworthy that the total irreversibility of the hybrid plant compared to the power output is significantly lower than the standard plant (Table 1).

Table 2. Exergy breakdown of the hybrid plant.

\begin{tabular}{lccc}
\hline Process & Heat Input (MW) & Power Output (MW) & Irreversibility (MW) \\
\hline Compression & & -12.4 & 1.1 \\
Fuel Cell & 42.0 & 23.4 & 4.7 \\
Combustion & 14.0 & & 4.1 \\
Expansion & & 26.0 & 1.5 \\
Heat Exchange/Mixing & & & 4.8 \\
TOTAL & 56.0 & 37.0 & 16.2 \\
\multicolumn{1}{c}{$1^{\text {st }}$ Law Efficiency } & $66.2 \%$ & $2^{\text {nd }}$ Law Efficiency & $47.0 \%$ \\
\hline
\end{tabular}

All capital costs and payback periods are shown in Table 3. Note that these only include the cost of adding the SOFC to the power plant. The combustor, turbine and compressors already exist, thus are not accounted for in the costing. The fuel cost refers to the annual cost of additional fuel required for the hybrid plant. The existing plant consumes fuel at the rate of $40 \mathrm{~kg} / \mathrm{min}$, while the hybrid plant requires $66.7 \mathrm{~kg} / \mathrm{min}$ of fuel. The power gain refers to the revenue potential of generating power above that which is currently being produced. Presently the plant produces $10 \mathrm{MW}$ of power, while the hybrid produces $37 \mathrm{MW}$. These values reveal that the fuel to power conversion increases by $120 \%$. 
Table 3. Cost breakdown for the hybrid plant (USD \$M).

\begin{tabular}{lcc}
\hline Component & Capital Cost & Annual Gain (Cost) \\
\hline SOFC Stack & 20.1 & \\
Inverter & 1.5 & \\
Pre-reformer & 0.2 & \\
SOFC Auxiliary & 2.0 & \\
SOFC TOTAL & 23.8 & \\
\hline Heat Exchangers & 2.3 & $(2.3)$ \\
Fuel Costs & & 11.9 \\
Power Gains & & \\
NPV & 34.9 & \\
Payback Period & 3.3 years & \\
\hline
\end{tabular}

This scheme of using the SOFC exhaust to preheat the inlet gases results in a higher operational temperature of the SOFC. However, it must be noted that the $1410 \mathrm{~K}$ SOFC temperature is too high considering material constraints. In practice it is desirable to slightly reduce this by bypassing some fuel directly to the afterburner. This would slightly decrease the system efficiencies as it entails more combustion and less fuel cell processes. But it would preserve the life of the SOFC.

Another issue that arises out of this research is the size of the SOFC required for optimum integration with the gas turbine. 23.4 MW is larger than any SOFC in existence. Most existing systems operate in the $\mathrm{kW}$ range, and most proposed systems are less than $10 \mathrm{MW}$. However, it should be noted that this is in the same order of magnitude as projected future SOFC systems [26,27]. The gas distribution systems and cooling systems would also have to be specially designed for the plant in question, which are practical issues to consider before such a system can be built.

Another point to note is the total power produced by the hybrid plant - $37 \mathrm{MW}$ compared to $10 \mathrm{MW}$ for the original plant. This is primarily because of the addition of the SOFC, as well as greater gas handling by the gas turbine. This means that the hybrid power plant produces almost four times as much power as the original standard plant. This alleviates the need for constructing new power plants. As a point of comparison, the entire hybrid system would cost $\$ 32 \mathrm{M}$ to produce $37 \mathrm{MW}$, while an equivalent GT power plant using the same rate of natural gas would cost $\$ 9.6 \mathrm{M}$ but only produce $17 \mathrm{MW}$ of power. Overall the SOFC hybrid system can reduce the cost of energy to $\$ 0.033 / \mathrm{kWh}$ compared to $\$ 0.05 / \mathrm{kWh}$ for an equivalent GT system. This offers decision makers an option of producing more power at a higher efficiency and lower cost. Note that these are all based on future mass production SOFC cost projections. There may also be practical issues associated with the setting up of an SOFC system upstream of an existing gas turbine. This may entail shutting down the plant for a period of time. However, these issues are not discussed here, as these issues will arise whenever new power plants are constructed. Future works will focus on resolving many of the practical issues raised in this work. 


\section{Conclusions}

A thermo-economic model was developed and used to optimize a SOFC-GT hybrid power plant for providing stationary and distributed electrical power. The focus was not on designing new power plants at the micro-level for distributed power, but retrofitting existing power plants. Results show that the overall thermal efficiency can be increased from $30.0 \%$ to $66.2 \%$ while the second law efficiency can be increased from $13.7 \%$ to $47.0 \%$. A net present value of $\$ 34.9 \mathrm{M}$ is expected based on future mass production SOFC costs, which represents a payback period of less than four years on the capital investment. The optimum hybrid plant generates $37 \mathrm{MW}$ of power, nearly four times more than the original plant, which precludes the need for building new power plants.

\section{Acknowledgements}

The author wishes to express his sincere gratitude to the University of Trinidad and Tobago for its support of this work.

\section{References and Notes}

1. EG\&G Technical Services. Fuel Cell Handbook, 7th ed.; US Department of Energy: Morgantown, WV, USA, 2003.

2. Zhang, X.; Chan, S.H; Li, G.; Ho, H.K.; Li, J.; Feng, Z. A review of integration strategies for solid oxide fuel cells. J. Power Source 2010, 195, 685-702.

3. Litzinger, K.P. Comparative evaluation of SOFC gas turbine hybrid options. In Proceedings of the ASME Turbo Expo Conference, Reno, NV, USA, June 2005.

4. Agnew, D.G.D. The design and integration of the rolls royce fuel cell systems 1MW SOFC. In Proceedings of the ASME Turbo Expo Conference, Reno, NV, USA, June 2005.

5. Traverso, A; Pascenti, M.; Ferrari, M.L.; Bertone, R.; Magistri, L. Hyrbid simulation facility based on commercial $100 \mathrm{kWe}$ micro gas turbine. In Proceedings of the ASME Fuel Cell Conference, Irvine, CA, USA, June 2007.

6. Massardo, A.F.; Lubelli, F. Internal reforming solid oxide fuel cell-gas turbine combined cycles (IRSOFC-GT): Part A-Cell model and cycle thermodynamic analysis. J. Engine Gas Turbines Power 2000, 122, 27-35.

7. Chan, S.H; Low, C.F.; Ding, O.L. Energy and exergy analysis of a simple SOFC power system. J. Power Source 2002, 103, 188-200.

8. Bavarsad, P.G. Energy and exergy analysis of internal reforming solid oxide fuel cell-gas turbine hybrid system. Int. J. Hydrogen Energy 2007, 32, 4591-4599.

9. Calise, F.; d'Accadia, M.D.; Palombo, A.; Vanoli, L. Simulation and exergy analysis of a hybrid solid oxide fuel cell (SOFC)-gas turbine system. Energy 2006, 31, 3278-3299.

10. Song, T.W.; Sohn, J.L.; Kim, T.S.; Ro, S.T. Performance characteristics of a MW-class SOFC/GT hybrid system based on a commercially available gas turbine. J. Power Source 2006, 158, 361-367.

11. Akkaya, A.V.; Sahin, B.; Erdem, H.H. Thermodynamic model for exergetic performance of a tubular SOFC module. Renew. Energy 2009, 34, 1863-1870. 
12. Haseli, Y.; Dincer, I.; Naterer, G.F. Thermodynamic modeling of a gas turbine cycle combined with a solid oxide fuel cell. Int. J. Hydrogen Energy 2008, 33, 5811-5822.

13. Haseli, Y.; Dincer, I.; Naterer, G.F. Thermodynamic analysis of a combined gas turbine power system with a solid oxide fuel cell through exergy. Thermochimica Acta 2008, 480, 1-9.

14. Akkaya, A.V.; Sahin, B.; Erdem, H.H. An analysis of SOFC/GT CHP system based on exergetic performance criteria. Int. J Hydrogen Energy 2008, 33, 2566-2577.

15. Burbank Jr, W.; Witmer, D.; Holcomb, F. Model of a novel pressurized solid oxide fuel cell gas turbine hybrid engine. J. Power Source 2009, 193, 656-664.

16. Calise, F.; Palombo, A.; Vanoli, L. Design and partial load exergy analysis of hybrid SOFC-GT power plant. J. Power Source 2006, 158, 225-244.

17. Franzoni, A.; Magistri, L.; Traverso, A.; Massardo, A.F. Thermoeconomic analysis of pressurized hybrid SOFC systems with $\mathrm{CO}_{2}$ separation. Energy 2008, 33, 311-320.

18. Palazzi, F.; Autissier, N.; Marechal, F.M.A.; Favrat, M.D. A methodology for thermo-economic modeling and optimization of solid oxide fuel cell systems. Appl. Therm. Eng. 2007, 27, 2703-2712.

19. Arsalis, AM. Thermoeconomic modeling and parametric study of hybrid SOFC-gas turbine-steam turbine power plants ranging from 1.5 to 10 MWe. J. Power Source 2008, 181, 313-326.

20. Santin, M.; Traverso, A.; Magistri, L.; Massardo, A.F. Thermoeconomic analysis of SOFC-GT hybrid systems fed by liquid fuels. Energy 2009, doi:10.1016/j.energy.2009.06.012.

21. Calise, F.; d'Accadia, M.D.; Vanoli, L.; von Spakovsky, M.R. Single-level optimization of a hybrid SOFC-GT power plant. J. Power Source 2006, 159, 1169-1185.

22. Chan, S.H.; Ho, H.K.; Tian, T. Multi-level modeling of SOFC-gas turbine hybrid system. Int. J. Hydrogen Energy 2003, 28, 889-900.

23. Bao, C.; Shi, Y.; Li, C.; Cai, N.; Su, Q. Multi-level simulation platform of SOFC-GT hybrid generation system. Int. J. Hydrogen Energy 2009, doi:10.1016/j.ijhydene.2009.05.047.

24. Zhang, X.; Li, J.; Li, G.; Feng, Z. Dynamic modeling of a hybrid system of the solid oxide fuel cell and recuperative gas turbine. J. Power Source 2006, 163, 523-531.

25. Kandepu, R.; Imsland, L.; Foss, B.A.; Stiller, C. Modeling and control of a SOFC-GT-based autonomous power system. Energy 2007, 32, 406-417.

26. Singhal, S.C.; Kendall, K. High Temperature Solid Oxide Fuel Cells; Elsevier: London, UK, 2003.

27. Larminie, J.; Dicks, A. Fuel Cell Systems Explained; John Wiley and Sons: Chichester, UK, 2003.

28. Winterbone, J.; Dicks, A. Advanced Thermodynamics for Engineers; Butersworth-Heinemann: Oxford, UK, 1996.

29. Incroperra, F.P.; DeWitt, D.P. Fundamentals of Heat and Mass Transfer; John Wiley and Sons: Hoboken, NJ, 2006.

30. Akkaya, A.V. Electrochemical model for performance analysis of a tubular SOFC. Int. J. Energy Res. 2007, 31, 79-98.

31. Singhal, S.C. Recent progress in tubular solid oxide fuel cell technology. Fifth International Symposium on Solid Oxide Fuel Cells, Aachen, Germany, June 1997.

(C) 2010 by the authors; licensee Molecular Diversity Preservation International, Basel, Switzerland. This article is an open-access article distributed under the terms and conditions of the Creative Commons Attribution license (http://creativecommons.org/licenses/by/3.0/). 